\title{
Correction to: The 1000IBD project: multi- omics data of 1000 inflammatory bowel disease patients; data release 1
}

Floris Imhann ${ }^{1,2}$, K. J. Van der Velde ${ }^{2}$, R. Barbieri ${ }^{1,2}$, R. Alberts ${ }^{1,2}$, M. D. Voskuil ${ }^{1,2}$, A. Vich Vila ${ }^{1,2}$, V. Collij ${ }^{1,2}$,

L. M. Spekhorst ${ }^{1,2}$, K. W. J. Van der Sloot ${ }^{1}$, V. Peters ${ }^{1}$, H. M. Van Dullemen ${ }^{1}$, M. C. Visschedijk1 , E. A. M. Festen ${ }^{1,2}$, M. A. Swertz ${ }^{2}$, G. Dijkstra ${ }^{1^{*}}$ and R. K. Weersma ${ }^{1 *}$

\section{Correction to: BMC Gastroenterology (2019) 19:5 \\ https://doi.org/10.1186/s12876-018-0917-5}

Following publication of the original article [1], the authors reported two names have been erroneously spelled as Festen EAM and Van der Sloot KWJ. The correct names are E.A.M. Festen and K.W.J. van der Sloot.

It has been corrected in the original article as well.

The publisher apologizes for any inconvenience caused by this error.

\footnotetext{
Author details

'Department of Gastroenterology and Hepatology, University of Groningen and University Medical Center Groningen, PO Box 30.001, 9700RB Groningen, the Netherlands. ${ }^{2}$ Department of Genetics, University of Groningen and University Medical Center Groningen, Groningen, the Netherlands.
}

Received: 23 January 2019 Accepted: 23 January 2019

Published online: 27 March 2019

\section{Reference}

1. Imhann, et al. BMC Gastroenterol. 2019;19:5. https://doi.org/10.1186/s12876018-0917-5.

\footnotetext{
* Correspondence: gerard.dijkstra@umcg.nl; r.k.weersma@umcg.nl

'Department of Gastroenterology and Hepatology, University of Groningen and University Medical Center Groningen, PO Box 30.001, 9700RB Groningen, the Netherlands

Full list of author information is available at the end of the article
}

(c) The Author(s). 2019 Open Access This article is distributed under the terms of the Creative Commons Attribution 4.0 International License (http://creativecommons.org/licenses/by/4.0/), which permits unrestricted use, distribution, and reproduction in any medium, provided you give appropriate credit to the original author(s) and the source, provide a link to the Creative Commons license, and indicate if changes were made. The Creative Commons Public Domain Dedication waiver (http://creativecommons.org/publicdomain/zero/1.0/) applies to the data made available in this article, unless otherwise stated. 